\title{
Initial Teacher Education of Primary English and CLIL Teachers: An Analysis of the Training Curricula in the Universities of the Madrid Autonomous Community (Spain)
}

\author{
Alfonso López-Hernández \\ Universidad Pontificia Comillas, Madrid, Spain \\ https://orcid.org/0000-0001-8174-595X
}

\begin{abstract}
The Madrid Autonomous Community (Spain) offers a significant case of extensive bilingual (English) education provision in primary and secondary school, with over $50 \%$ of students following a Content and Language Integrated Learning (CLIL) programme. However, there are doubts about the ability of the current pre-service teacher education provision to meet the demands of the rapid growth of bilingual education in the region. This study analyses the initial teacher education (ITE) of English as a Foreign Language (EFL) and CLIL teachers in the Madrid community, by providing a systematic comparison of the 14 Primary Education teacher training degrees offered and, specifically, their EFL specialist itineraries. In particular, it assesses the balance between the development of linguistic and pedagogical competences, the linguistic requirements to enter the EFL track, and the inclusion of dedicated CLIL modules as part of the training curriculum. Results show that there is a great heterogeneity in the design of such programmes, especially regarding the value given to a language improvement component. Furthermore, it was found that the training in CLIL is insufficient, both in the core programmes and in the EFL itinerary. Beyond the Spanish context, the questions raised in this study can offer insight into the effective design of initial teacher education programmes for educational systems that have committed to mainstream bilingual education as a tool for enhancing foreign language competence.
\end{abstract}

Keywords: pre-service teacher education; initial teacher education, CLIL; EFL; higher education; bilingual education; Spain

\section{Introduction}

The aim of this study is to provide a critical overview of the initial teacher education (ITE) of primary school English teachers in the Madrid Autonomous Community (Spain), by analysing the role of English in general, and the EFL formative itinerary in particular, in the teacher training programmes offered by 
the numerous public and private universities found in a region with over 6.5 million residents.

The comparison is a timely one, as it comes ten years after the creation of the new teacher training degrees in Spain, following the national educational reform (Order 3857/2007, 27th of December) that aligned Spanish teacher training degrees with the European Higher Education Area (EHEA), in what became known as the Bologna Process. Amongst other targets, the reform aimed at offering teacher trainees a more generalist training in the subjects of primary education, somewhat neglecting the former specialist degrees (in TEFL, Physical Education., Speech and Language Therapy, Special Needs Education, etc.) of the year 2000 educational law. In the new EHEA degrees, trainees willing to specialise may choose from a number of formative itineraries or tracks, called menciones, which offer significantly fewer modules and credits than the former specialised degrees, and tend to concentrate them in the last two years of students' training.

Paradoxically, such a turn away from specialisation has coincided with a heightened social and professional awareness of the role of English as the world's lingua franca, resulting in greater pressure on educational systems to provide more extensive and effective foreign language training (Eurydice, 2017), especially considering that the average competence in EFL among Spaniards is still poor compared to most other European countries (English First, 2020; European Commission, 2012a, 2012b). Interestingly, regional educational authorities have tried to meet this demand, not so much through an increase in hours of English taught in school, but by committing to offering Content and Language Integrated Learning programmes, in which English is also used as a vehicle of instruction. Indeed, most autonomous communities in Spain have developed some form of CLIL (Scott \& Beadle, 2014), to the point that Spain can be considered to be the European spearhead of CLIL research and practice (PerezCañado, 2016). In sum, in a time when primary teachers are required to teach more English and other subjects in English, the number of credits devoted to foreign language teacher education in ITE is significantly lower than before the Bologna reform (Pérez Murillo \& Steele, 2017).

In this general context, the Madrid Autonomous Community stands out particularly as one of Europe's most extensive and ambitious cases of CLIL provision in primary and secondary education. Indeed, about $50 \%$ of students of public and concertado (semi-private) schools follow a CLIL English programme (Comunidad de Madrid, 2019) and most other students of semi-private and private schools receive some form of EMI or English reinforcement component, in the framework of programmes such as BEDA or UCETAM. ${ }^{1}$ As a result, it is fair

\footnotetext{
1 The Bilingual English Development and Assessment (BEDA) programme (https://www.ecmadrid.org/en/programs/beda-program) is run by the association of Roman Catholic schools of Madrid in partnership with Cambridge English Language Assessment. In turn, UCETAM, an association of private and semi-private schools, awards the CBC (cooperative bilingual school certification) o some of its schools. (See https://colegiosbilinguescooperativos.com/cbc/) Both programmes are compatible with the regional authority's extensive bilingual education programme for public and publicly funded schools.
} 
to say that many - if not most - teacher trainees in the Madrid region can expect to be in close contact with English as soon as they begin their teaching careers: whether as English specialist teachers, teachers of other subjects in English, or teachers of classes taught in Spanish who work in a CLIL school.

There are a number of studies that discuss the training needs of pre-service English and CLIL teachers in the Spanish context (e.g., Cabezuelo \& Fernández, 2014; Fernández-Viciana \& Fernández-Costales, 2017; Gutiérrez Gamboa \& Custodio Espinar, 2021; Pavón et al., 2020). As to the curricular design of ITE programmes, the main study is that of De la Maya Retamar and Luengo González (2015), in which 60 primary education teacher training programmes at the national level were surveyed. However, as suggested above, the special bilingual educational scenario found in the Madrid Autonomous Community suggests the need of a closer look at the regional ITE provision, as a case study that can help to shed light on the specific challenges of ITE curricular design in countries and regions that require to effectively train large numbers of non-native foreign language and CLIL practitioners.

\section{Research questions}

This study analyses the responses provided by public and private higher education institutions to the increasing need for qualified EFL and CLIL primary teachers in the Madrid region. To do so, it addresses the following research questions:

Research question 1: To what extent does the curricular design of the generalist EHEA ITE programmes in Madrid universities reflect the rise of English as a lingua franca, as well as the higher demand for qualified English and CLIL primary teachers in the region?

Research question 2: What, if any, are the linguistic requirements for trainees who wish to enter the EFL formative itinerary at the universities?

Research question 3: What is the balance between English language improvement, foreign language pedagogy and other areas in the different universities' curricular design of the EFL formative itinerary?

Research question 4: What is the role of training in CLIL in the different ITE programmes, both inside and outside the specialist EFL itinerary?

Before analysing the university curricula, the first part of this paper discusses the training needs of primary EFL and CLIL teachers in the Madrid region, and provides an overview of the changes in the Spanish higher education framework that help to explain the nature and current role of the menciones [formative itineraries] in the teacher training degrees.

\section{Training demands on pre-service teacher education}

The first question that needs to be addressed concerns the specific demands made by the educational system on ITE, especially in the area of EFL. 


\subsection{The role of language improvement}

In line with the competency-based paradigm that guided the reform of the Spanish higher education degrees, the Spanish Agency for Quality in Education (ANECA, 2005, p. $113 \mathrm{ff}$.) provided a list of specific professional competencies that teacher trainees should develop in order to be able to teach the school curricula effectively. They were divided into three types: disciplinary knowledge (knowing), professional (knowing how to) and trans-national competencies (ANECA 2005; Madrid Fernández, 2014).

In the case of foreign language teaching, it is interesting to note the emphasis given to "full communicative competence in the target language", as the first disciplinary content. The inclusion of such linguistic competence reflects the predominance of the communicative language teaching (CLT) paradigm at the time, but also the important fact that, in the Spanish context, which is defined by a generally low mastery of English as a foreign language (English First, 2020; European Commission, 2012a, 2012b), linguistic competence in the target language should not be taken for granted, even among trainees who choose to specialise in the EFL subject.

In fact, several studies conducted on Spanish teacher trainees studying the EFL specialist itinerary have shown that language improvement is perceived as a crucial component of their training. Amengual-Pizarro (2007) found that prospective language teachers in the Balearic Islands considered that there should be a balanced combination between language improvement and methodology in their pre-service training, considering that they will be expected to teach English to young learners following a communicative approach. In a more recent study with trainees following different formative itineraries (not just EFL), the same author found that students feel that the current primary education degree does not provide the necessary training for them to teach English effectively to children, and identified the lack of English language proficiency, especially oral, as their main shortcoming as future English teachers (Amengual-Pizarro, 2013).

In line with Amengual-Pizarro's findings, another study, conducted with prospective EFL teachers in a different university (Fernández-Viciana \& Fernández-Costales, 2017), concluded that a perceived low competence in English is one of the factors that most negatively affects their self-efficacy as foreign language teachers. As a result, the participants demanded more language improvement, especially focused on language related to their profession (teaching). This latter request is consistent with voices such as Freeman (2016) and Richards (2017), who argue for a functional, "ESP" type approach in ITE programmes, especially in countries where average general proficiency in English is low.

Overall, the voice of Spanish student teachers supports the view, shared by many other non-native English teachers across different continents (Richards, 2017), that a poor proficiency in English will negatively affect not only the teachers' performance in class, but also their sense of self-efficacy and even their identification with the ELT community (Young et al., 2014). Hence, when looking 
at specific teacher training programmes in the Spanish context, it will be important to consider to what extent this need is addressed.

\subsection{Training for CLIL}

As Flores (2011) claims, 'understanding the nature and purpose of teacher education implies an analysis of the conceptual and epistemological assumptions underpinning its models and organisational systems, but it also entails the consideration of the social, political, cultural and economic context in which it is embedded.'; In the case of the Madrid Autonomous Community, the educational context of the last years has been crucially affected by the rapid growth of bilingual education programmes and, most notably, the community's bilingual programme for public and semi-private schools. As of 2019, there were 399 bilingual public primary schools, 181 public secondary schools and 216 semiprivate schools offering the bilingual programme in primary or primary and secondary school. Furthermore, the programme was recently expanded to infant education (ages 3-6), both in public and semi-private schools. In total, close to 200,000 students participate in this government-funded programme, accounting for approximately $50 \%$ of the student population in compulsory stages of education in publicly funded schools (Comunidad de Madrid, 2019).

Without discussing this programme in detail, it is worth noting that it claims to offer instruction of subjects in English following a CLIL approach. Content and Language Integrated Learning has been used as an umbrella term for the different context-bound varieties of bilingual education offered across Europe, that nevertheless share 'a dual-focused educational approach in which an additional language is used for the learning and teaching of both content and language' (Coyle et al., 2010, p.1). Moreover, there is a wide consensus among CLIL researchers and practitioners that CLIL is much more than translating instruction into an additional language; rather, it must seek to promote a strong cognitive element, as well as develop inter-cultural competence in students, to mention but two of CLIL's central tenets. To put CLIL into practice effectively, there are a number of key competences that CLIL practitioners must possess, and which have been identified by recent research: linguistic and pedagogical, of course, but also scientific, organisational, interpersonal and collaborative, and reflective and developmental, to use Pérez-Cañado's (2018) CLIL teacher profile.

In what relates to the scope of this paper, there are serious doubts as to the ability of teacher education provision to adapt to the needs of CLIL. Pérez-Cañado (2018, p. 213) believes that 'the demands placed by the implementation of this approach have been largely overlooked.' Moreover, existing ITE programmes are criticised for not offering sufficient methodological training in CLIL (De la Maya Retamar \& Luengo González, 2015), and generally not being in line with the new teacher demands (Cabezuelo Gutiérrez \& Fernández Fernández, 2014). To meet them, recommendations include pre-service and in-service training modules (Madrid Manrique \& Madrid Fernández, 2014; Pavón et al., 2020; Pérez-Cañado, 2018), as well as offering EMI (English as Medium of Instruction) teacher training programmes at both the bachelor and master's levels (Pérez-Cañado, 2018). 
The need for an enhanced role of CLIL in ITE is even more urgent in the Madrid Autonomous Community, owing to changes in the requirements to obtain linguistic capability certification (habilitación lingüística, in Spanish), which qualifies teachers to teach subjects in English. Before 2010, there was an Initial Training Plan that combined language improvement and methodological training (in CLIL), but, since 2010-11, certification is granted following purely linguistic criteria, requiring a level of English of $\mathrm{C} 1$ (CEFR), which may be demonstrated by different means (Cabezuelo Gutiérrez \& Fernández Fernández, 2014). On top of that, in-service training in CLIL, although offered, is voluntary and not tied to the aforementioned process of certification. The current scenario offers the interesting paradox, outlined by Custodio Espinar (2020), that, at a time when teachers are in dire need of methodological training in CLIL, there is no effective guarantee that they receive it either prior to, or during, their careers as CLIL practitioners.

Therefore, an assessment of ITE in the Madrid region must also consider the role of CLIL in the different programmes: whether a specific CLIL module is taught inside or outside the EFL formative itinerary, and whether some form of EMI teacher education programme is offered.

\section{The pre-service training of English and CLIL teachers in Spain: generalist degrees and formative itineraries}

We now turn to a brief discussion of the legal and academic framework in which universities and other tertiary level institutions plan their curricula in order to address the training demands outlined in the previous section.

As was suggested in the introduction, the current menciones or formative itineraries in Spanish teacher training degrees have resulted from the tension created by two conflicting demands in ITE: providing a more generalist training in primary education, on the one hand, and the need to train specialist teachers in such subjects as Physical Education or EFL. It must be noted that, in the Spanish tradition, foreign languages in primary education have been taught by specialist, not generalist or class teachers (Eurydice, 2017) as is the case in some countries with a longer tradition in foreign language education, such as Scandinavian ones (Jover et al., 2016). Interestingly, the discussions leading to the EHEA educational reform did envisage the possibility of training all student teachers in FL education, but decided to postpone this scenario until a moment in time that was 'difficult to predict' (ANECA, 2005).

In this generalist-oriented framework, universities were allowed to offer specialist formative itineraries, but these were not meant to replace the former specialist degrees. On the contrary, it was assumed that Education graduates would specialise through post-graduate studies (García Jiménez \& Lorente García, 2014). This assumption was probably unrealistic given the resources involved especially in the context of economic downturn and budget cuts - and so the Ministry of Education eventually established that EFL specialist teachers with an EHEA bachelor's degree would be required the EFL itinerary as well as a certified English language competence of B2 according to the Common European Framework of Reference (CEFR) (Royal Decree 1594/2011, November 4th). 
As a result, some itineraries, such as Physical Education or English, have, accidentally, come to replace the former specialist qualifications. Albeit, as recent studies point out (Amengual-Pizarro, 2013; De la Maya Retamar \& Luengo González, 2015), the new formative itineraries have significantly reduced the number of credits allocated to training student teachers in the specialist subject. To cite but one example, the pre-EHEA EFL degree offered at Autonomous University, one of the largest public universities in the region, offered close to 60 credits in EFL-related contents, amounting to almost twice the number of similar credits taught today (Resolution, Autonomous University of Madrid, 26th June, 2000).

An analysis of the universities' respective programmes should, therefore, consider (a) whether they have attempted to compensate this lack of training in EFL outside of the specialist itinerary (i.e., in the core modules of the primary education degree) as well as (b) what choices have been made in order to make the best possible use of the reduced credit load devoted to foreign language teacher education.

\section{Method}

This study focuses on the ITE of primary teachers who are likely to pursue teaching careers in the Madrid Autonomous Community. Hence, although based in Madrid, online universities such as UNIR or UNED have been disregarded, as their student intake comes from all over the country, as well as from abroad. As a result, a total of 14 training programmes taught at 14 universities in the academic year 2019-2020 have been surveyed.

This research can be considered a case of comparative programme evaluation (Frey, 2018), and employs a qualitative methodology that blends document analysis and personal interviews (Owen, 2014). Data on the different programmes were obtained from their institutional websites, and then systematically classified and tabulated. Furthermore, department heads or programme coordinators were contacted in order to confirm or clarify some of the data, thus ensuring their credibility. In particular, they provided useful details that were not available in published documentation, including the required language level to enter the itinerary, the methodological training received by faculty teaching in EMI programmes, and the attention given to CLIL in those programmes that lack a dedicated bilingual education module.

The data obtained were then analysed from both statistical and interpretive viewpoints (Nunan, 2013), resulting in the graphic representation and discussion presented below.

Finally, when comparing the structure of the specialist itineraries, credits allotted to practicum and end-of-degree dissertations (TFG, in its Spanish acronym) have been disregarded. Although such credits can offer a significant contribution to students' training, the great heterogeneity in their implementation makes them unsuitable for cross-programme comparison. 


\section{Results and discussion}

6.1. Overview of the ITE programmes in the Madrid Autonomous Community In all, there are 14 universities or colleges based in the Madrid Autonomous Community that offer the primary education teacher training bachelor's degree. Of them, four are public universities, five are private, and the remaining five are private colleges affiliated with a public institution, called centros adscritos. ${ }^{2}$ Eight of these institutions offer traditional on-site tuition only, five provide both faceto-face and distance learning programmes, and only one university (UDIMA) teaches the degree exclusively online.

Tables 1-3 provide an overview of the teacher training courses in the three kinds of institutions discussed. The tables also specify the type of learning offered, which formative itineraries can be studied, and whether there is an EMI stream that can be followed.

Table 1: Overview of primary education ITE programmes in the Madrid Autonomous Community. Public universities.

\begin{tabular}{|c|c|c|l|}
\hline University & $\begin{array}{c}\text { Type of } \\
\text { learning }\end{array}$ & $\begin{array}{c}\text { EMI } \\
\text { programme } \\
\text { (Yes/No) }\end{array}$ & \multicolumn{1}{|c|}{ Formative itineraries } \\
\hline $\begin{array}{c}\text { Complutense } \\
\text { University of } \\
\text { Madrid (UCM) }\end{array}$ & On-site & Y & $\begin{array}{l}\text { EFL, Speech and Language } \\
\text { Therapy, Physical Education, } \\
\text { Music }\end{array}$ \\
\hline $\begin{array}{c}\text { Autonomous } \\
\text { University of } \\
\text { Madrid (UAM) }\end{array}$ & On-site & $\mathrm{N}$ & $\begin{array}{l}\text { EFL, Arts, ICT, Music, } \\
\text { Therapeutic pedagogy, Speech } \\
\text { and Language Therapy, Physical } \\
\text { Education. }\end{array}$ \\
\hline $\begin{array}{c}\text { University of } \\
\text { Alcalá (UAH) }\end{array}$ & On-site & $\mathrm{Y}$ & $\begin{array}{l}\text { EFL, Arts, Special Needs } \\
\text { Education, Spanish Language } \\
\text { and Literature, Physical } \\
\text { Education, Natural Science. }\end{array}$ \\
\hline $\begin{array}{c}\text { Rey Juan Carlos } \\
\text { University } \\
\text { (URJC) }\end{array}$ & $\begin{array}{c}\text { On-site, } \\
\text { distance }\end{array}$ & $\mathrm{Y}$ & EFL, Physical Education, Music. \\
\hline
\end{tabular}

\footnotetext{
2 These affiliated institutions are private; however, their degrees are awarded by the public institution they are affiliated with. Note that the curricula of their degrees they offer are identical or very similar to the ones of the equivalent degrees at the public university.
} 
Table 2: Overview of primary education ITE programmes in the Madrid Autonomous Community. Private colleges affiliated with public universities (in brackets).

\begin{tabular}{|c|c|c|l|}
\hline University & $\begin{array}{c}\text { Type of } \\
\text { learning }\end{array}$ & $\begin{array}{c}\text { EMI } \\
\text { programme } \\
\text { (Yes/No) }\end{array}$ & \multicolumn{1}{|c|}{ Formative itineraries } \\
\hline $\begin{array}{c}\text { CES Don Bosco } \\
\text { (UCM) }\end{array}$ & On-site & $\mathrm{Y}$ & $\begin{array}{l}\text { EFL, Speech and language } \\
\text { therapy, Physical Education, } \\
\text { Music, Therapeutic Pedagogy }\end{array}$ \\
\hline $\begin{array}{c}\text { ESCUNI (UCM) } \\
\text { CES Villanueva } \\
\text { (UCM) }\end{array}$ & On-site & $\mathrm{N}$ & $\begin{array}{l}\text { EFL, Physical Education, } \\
\text { Therapeutic Pedagogy }\end{array}$ \\
\hline $\begin{array}{c}\text { CSEU Lasalle } \\
\text { (UAM) }\end{array}$ & $\begin{array}{c}\text { On-site, } \\
\text { distance }\end{array}$ & $\mathrm{N}$ & $\begin{array}{l}\text { EFL, Music, Physical Education, } \\
\text { Therapeutic Pedagogy } \\
\text { Speech and Language Therapy }\end{array}$ \\
\hline $\begin{array}{c}\text { Cardenal } \\
\text { Cisneros (UAH) }\end{array}$ & $\begin{array}{c}\text { On-site, } \\
\text { distance }\end{array}$ & $\mathrm{Y}$ & $\begin{array}{l}\text { EFL, Physical Education, Special } \\
\text { Needs Education }\end{array}$ \\
\hline
\end{tabular}

Table 3: Overview of primary education ITE programmes in the Madrid Autonomous Community. Private universities.

\begin{tabular}{|c|c|c|l|}
\hline University & $\begin{array}{c}\text { Type of } \\
\text { learning }\end{array}$ & $\begin{array}{c}\text { EMI } \\
\text { programme } \\
\text { (Yes/No) }\end{array}$ & \multicolumn{1}{|c|}{ Formative itineraries } \\
\hline $\begin{array}{c}\text { Comillas } \\
\text { Pontifical } \\
\text { University }\end{array}$ & On-site & $\mathrm{N}$ & EFL, Therapeutic Pedagogy \\
\hline $\begin{array}{c}\text { Francisco de } \\
\text { Vitoria } \\
\text { University } \\
\text { (UFV) }\end{array}$ & On-site & $\mathrm{N}$ & $\begin{array}{l}\text { EFL, Physical Education, Music, } \\
\text { Therapeutic Pedagogy. }\end{array}$ \\
\hline $\begin{array}{c}\text { Camilo José } \\
\text { Cela University } \\
\text { (UCJC) }\end{array}$ & $\begin{array}{c}\text { On-site, } \\
\text { distance, } \\
\text { blended }\end{array}$ & $\mathrm{Y}$ & $\begin{array}{l}\text { EFL, Physical Education, } \\
\text { Therapeutic Pedagogy, Speech } \\
\text { and Language Therapy, Music, } \\
\text { ICT in Education. }\end{array}$ \\
\hline $\begin{array}{c}\text { Madrid Open } \\
\text { University } \\
\text { (UDIMA) }\end{array}$ & Distance & $\mathrm{N}$ & $\begin{array}{l}\text { EFL, Therapeutic Pedagogy, } \\
\text { Speech and Language Therapy, } \\
\text { ICT in education }\end{array}$ \\
\hline $\begin{array}{c}\text { Antonio de } \\
\text { Nebrija } \\
\text { University }\end{array}$ & $\begin{array}{c}\text { On-site, } \\
\text { distance }\end{array}$ & $\mathrm{Y}$ & $\begin{array}{l}\text { EFL, Therapeutic Pedagogy, } \\
\text { Physical Education, French, } \\
\text { Speech and Language Therapy }\end{array}$ \\
\hline
\end{tabular}


Considering the overall picture, the number of new programmes that have been created following the EHEA reform is striking. Indeed, out of the 14 institutions that currently offer the primary education teacher training degree, only 10 of them taught the former, pre-EHEA teacher training programmes, and one (Universidad Francisco de Vitoria) did not offer the EFL specialist degree (Comunidad de Madrid, 2006). It is also telling that four of these new programmes have been implemented by private universities, which seem to have found in teacher training a fruitful domain to increase their student intake.

Private institutions also lead the way as regard online and blended learning, with only one public university (URJC) offering a primary education teacher training programme online - which does not include the EFL formative itinerary. This can be explained by two reasons. Firstly, the greater need of private institutions to attract students in order to become profitable or at least survive, given the fact that they receive little or no direct government funding. Second, the fact that, at least traditionally, the role of providing distance education has been assigned to UNED, the Spanish Open University, with other public institutions focusing on on-site training as well as research.

\subsection{English in the core primary ITE curricula}

The fact that all of the teacher training faculties and departments offer the EFL formative itinerary attests to the high demand of qualified EFL and CLIL teachers in the region. The EFL one is among the most popular, which is consistent with research conducted in other regions (García Jiménez \& Lorente García, 2014) which found that trainees tend to enrol in formative itineraries that lead to a professional qualification, such as Physical Education or EFL. The offer of EMI degrees or streams in as many as half of the universities also reflects the popularity of EMI programmes in the region (Jeffrey et al. 2019; Ramos García, 2015) as well the perceived suitability of EMI instruction to train future CLIL teachers (Madrid Manrique \& Madrid Fernández, 2014; Pérez-Cañado, 2018).

However, it is also worth looking at the number of English Language, Teaching English as a Foreign Language (TEFL) and CLIL credits that are offered outside of the formative itinerary. Given the overall increase in degree credit load, and the reduction of the relative weight of specialist training, it would be expected that EHEA degrees would include a greater component of EFL-related core credits than in the past. This is found to be the case, although again there are significant differences between programmes. If, in the pre-EHEA courses, non-specialist primary trainees would study only 4.5 credits (that is, 45 hours of class time) of a subject named "English and its didactics" (See, for example, Resolution, Autonomous University of Madrid, 26 June, 2000), in the current degree courses the minimum number of ECTS credits is 10 (UCM and affiliated colleges), and the most common number is 12 , which amounts to two semester-long courses, approximately 100-120 hours of class time (See Figure 1).

These results also compare favourably with numbers at the national level. In their 2015 study, De la Maya Retamar and Luengo González found that half of the primary degrees sampled included only six credits of foreign language study, and 
only $18.3 \%$ offered 12 or more ECTS which, as they see it, would be the minimum required for a trainee entering with a CEFR B1 level to move on to B2, the minimum level required to obtain English teacher qualified status (De la Maya Retamar \& Luengo González, 2015).

On the other hand, some private universities offer a significantly higher number of English credits to their non-EFL specialist trainees, as many as 24 (Nebrija, UFV) and 17 (UCJC). Again, it would seem that private institutions are more responsive to labour market demands than public ones.

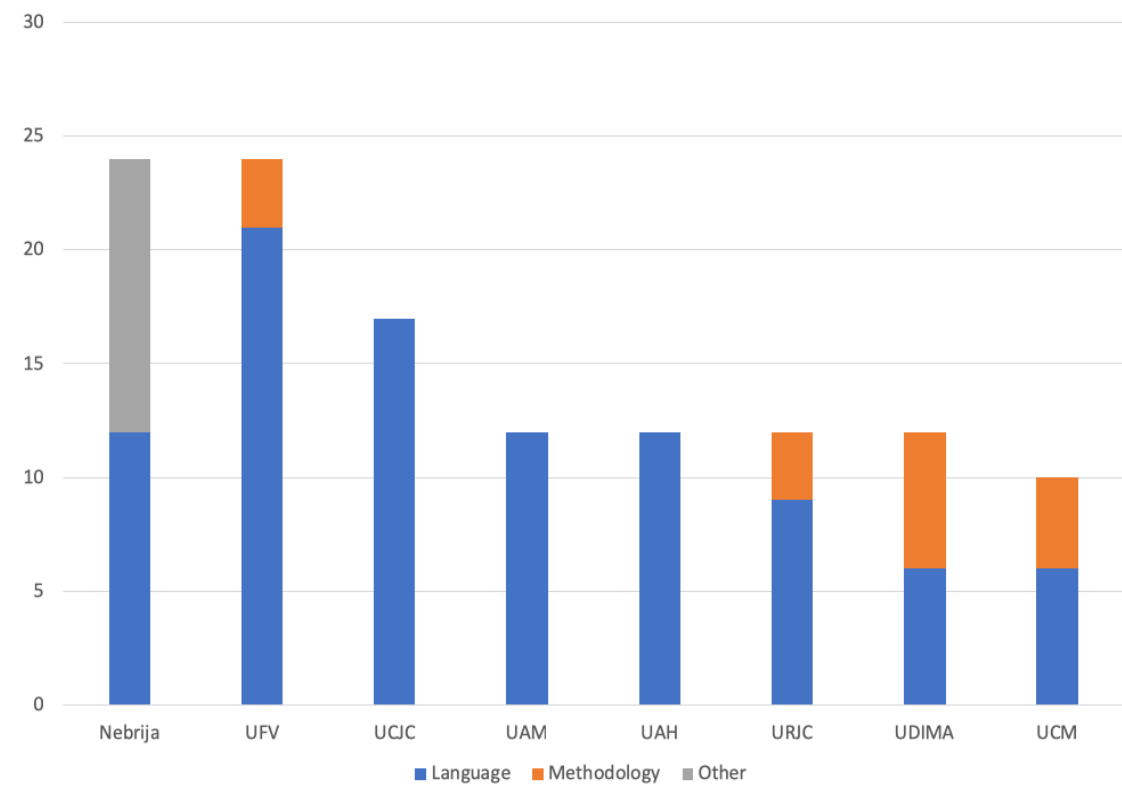

Figure 1: University curricula: ECTS of EFL-related coursework outside the EFL formative itinerary

Despite this encouraging overall picture, there are two significant pitfalls which must be addressed. Firstly, in six of the courses, including two of the largest public universities (UAM and UAH) and their affiliated colleges, students receive no explicit training in foreign language teaching methodology, as the credits are devoted to language improvement only (See Figure 1). This is consistent with the picture across the country, where over a third of the programmes offer no EFL methodology credits in the trainee's core training (De la Maya Retamar \& Luengo González, 2015), and reveals the worrying fact that a significant number of teachers will have completed their ITE without even an elementary understanding of the basic principles of one of the compulsory areas of the primary education curriculum.

Second, no less strikingly, none of the surveyed universities seems to train nonspecialist primary trainees in the principles, strategies and resources of Content and Language Integrated Learning, which, as we have seen, is one of the main thrusts of educational innovation in the region. Here, it could be argued that a number of universities are catering to this need by offering degrees that are partially taught in English, following strategies of EMI (Jover et al., 2016). Indeed, 
half of the analysed courses offer EMI streams that typically offer between $30 \%$ and $50 \%$ of the credit load in English.

Yet, there is a significant caveat that must be considered. While EMI instruction may serve to complement language improvement in significant ways, such as developing the Cognitive Academic Language Proficiency required from CLIL practitioners (Pérez Cañado, 2018), there is no guarantee that exposure to EMI will translate into a training in CLIL. Indeed, for student teachers to learn through their EMI experience, their lecturers must also apply CLIL instructional principles and strategies, which, in most cases, they have not been trained for. In this respect, programmes that offer their EMI lecturers methodological training, such as UAH, UCM, CES Don Bosco (Sierra Macarrón \& López Hernández, 2015) and, especially, Cisneros (Fernández \& Johnson, 2016), seem to be pointing in the right direction.

\subsection{The EFL formative itinerary: linguistic entry requirements}

The following sections compare the different EFL formative itineraries, by focusing on the minimum linguistic entry requirements, the balance of language improvement and TEFL in their curricular design and, finally, whether and how they provide training in CLIL.

The required levels of English language competence to enter the EFL itinerary are surprisingly heterogeneous, ranging from A2 (Comillas) to B2 (UAH, UCM, UCM-Villanueva). Overall, as can be seen in Figure 2, most courses settle on either the $\mathrm{B} 1$ or the $\mathrm{B} 2$ level, according to the CEFR.

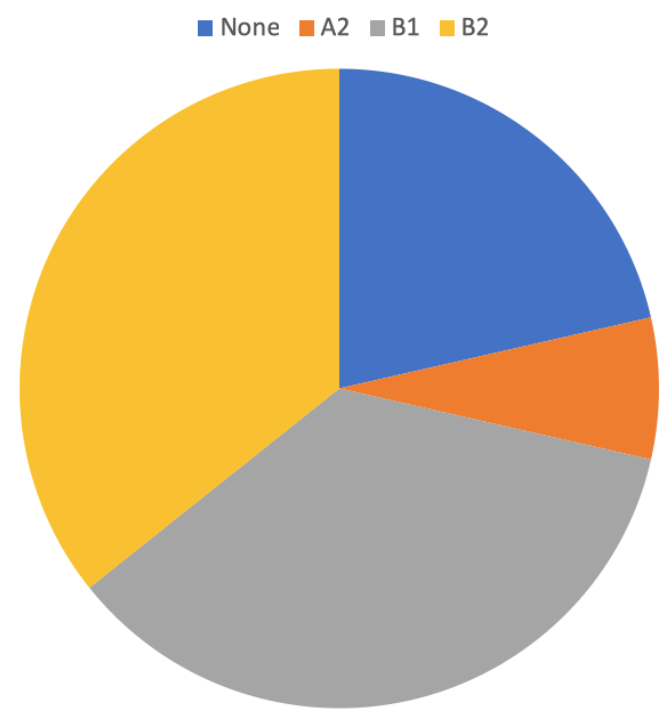

Figure 2: English language level, according to the CEFR, to enter the EFL itinerary

The high number of programmes (5) that require a B1 level appears to be surprising. This may be explained, of course, by non-pedagogical reasons, such as the desire to encourage a high enrolment in a formative itinerary that features among the most demanded by the labour market. In this respect, setting too high a level would probably deter many potential students from studying the EFL 
subject. However, it is worth noting that programmes that require an initial level of CEFR B1 or below also seem to provide the means for language improvement to take place. Indeed, they typically offer a relatively high number of credits devoted to mostly general English, taught normally through several years of the programme. This is the case, for instance, of Comillas, that, despite accepting trainees with an A2 level, offers 18 ECTS of language improvement in the first two years of the degree.

\subsection{Curricular design of the EFL itinerary}

Turning to the structure of the formative itinerary in the different universities and colleges, the first feature that can be noticed is that, compared to the former preEHEA specialist courses, the current programmes have streamlined their contents and, overall, devote less weight, if at all, to more philological contents such as morphosyntaxis, grammar, phonetics, culture or literature, that appeared as module names in the former specialist EFL teacher training degrees (see, for instance, the one taught at UAM [Resolution, Autonomous University of Madrid, $26^{\text {th }}$ June, 2000]). Indeed, as can be seen in Figure 3, most curricula prioritise a balance of language improvement and TEFL, with many of them offering a course on CLIL or bilingual education.

In what concerns the offer of modules outside language or methodology, the most popular choices are children's literature in English (taught in four programmes), culture and/or literature of English-speaking countries (3), and specific focus on teaching resources such as games (2), phonics or CALL. Phonetics and phonology, popular in the former specialist degrees, only appears in one of the surveyed formative itineraries. Lastly, there are no references to literacy, which has been hailed as the most effective approach for teaching English in CLIL contexts (Halbach, 2020).

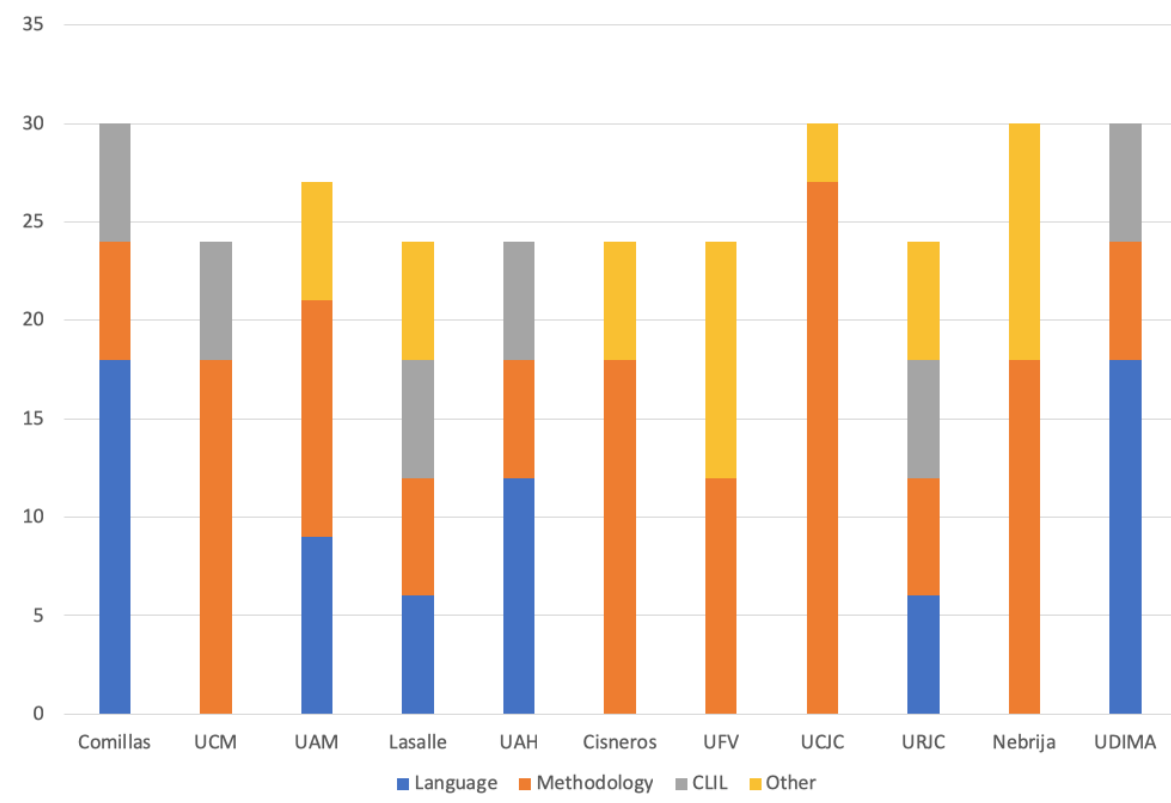

Figure 3: University curricula: distribution of coursework ECTS inside the EFL formative itinerary (excluding practicum and end-of-degree dissertation) 
However, here again, a closer look at the distribution of credits reveals a high heterogeneity in the balance of language, methodology and other contents that are offered as part of the itinerary.

In terms of the language improvement component, a clear distinction emerges between courses that rely heavily on it and those that do not. In the former group, we find the cases of Comillas, UAM, Lasalle, Alcalá, Rey Juan Carlos and UDIMA, which add more English credits to the ones already offered as a mandatory component of the primary education degree (See Figure 3). The other universities and colleges have left EFL coursework out of the itinerary and place the focus on methodological training in the form of modules devoted to TEFL, skills development, teaching resources, and so on.

Considering the sum total of language improvement credits at a given university - the aggregate of core and specialist credits - the range is astonishing, from 24 ECTS at UDIMA and Alcalá, to only six ECTS at Complutense and its affiliated colleges (Villanueva, Don Bosco, ESCUNI). Conversely, courses such as Alcala's and Lasalle's (UAM) devote a scanty six ECTS to training in TEFL, in contrast to 22 at UCM and affiliated colleges or a very high 27 at Camilo José Cela. It is worth noting that, in this regard, there is no evident line that can be drawn between the choices made by private and public universities.

Hence, not all the programmes are in line with the view that a language improvement component is crucial to enhance trainee's self-efficacy to teach English following a communicative approach (Amengual-Pizarro, 2007; Fernández-Viciana \& Fernández-Costales, 2017). In half of the programmes, language competence is either taken for granted, or its development left to EMI courses.

\subsection{Training in CLIL}

The last key feature of the formative itineraries that must be discussed is the role of Content and Language Integrated Learning in the formative itineraries' design. Whereas, as was seen before, CLIL plays no role in the core ITE syllabus of the different programmes, most formative itineraries - 9 out of 14 - offer some training in CLIL, normally as a dedicated module that is typically taught in the last year of the degree. In those cases where there is no explicit reference to CLIL, programme coordinators mentioned that CLIL is discussed in TEFL modules; or, in the case of Cardenal Cisneros, that training in CLIL is integrated into the EMI programme as a whole.

Still, the role of CLIL in EFL formative itineraries may reveal a number of questionable assumptions about the relationship of EFL and CLIL teacher education. The first one is that many or most future CLIL teachers will choose the EFL itinerary as part of their ITE. This belief is probably founded on the idea that trainees who enter their initial training with a high level of English will be inclined to pursue a career in teaching EFL. However, this is not necessarily the case. Firstly, because future Physical Education specialists - one of the most popular 
CLIL profiles - will need the P.E., not EFL, formative itinerary in order to work as CLIL teachers. Secondly, because many trainees who start their degrees with a high level of English may wish to follow an EMI programme, while not necessarily choosing the EFL itinerary. According to programme coordinators at Nebrija, Cardenal Cisneros, UAH and UCM, all of which offer EMI programmes, this is indeed the case to a lesser or greater degree.

The second assumption is that training in CLIL is, in many ways, an appendix of broader training in TEFL. This can be seen in the fact that CLIL modules are taught only as part of the EFL itinerary and, perhaps more tellingly, at the end of it. Such a belief could be warranted in cases of more language-driven CLIL programmes, the so-called 'soft' CLIL, in which CLIL is mainly taught as part of the FL curriculum, and by language teachers (Ball et al., 2016). However, this is clearly not the case in the Madrid region, where CLIL takes place mainly in the content subjects (Science, P.E., Arts and Crafts, Music), and is taught by subject, not foreign language, specialists. As has already been discussed, one of the practical implications of this assumption is that, in most cases, CLIL is not included in the core ITE curricula, thus failing to provide training to a significant number of future CLIL practitioners. An additional one is that, even in the context of the EFL itinerary, this training is offered too late in the degree for trainees to properly master CLIL pedagogy, methods and resources, and connect them both to the subject-specialist training they have received (Social Science, Arts \& Crafts, etc.) and, perhaps more importantly, to their teaching internships. Such shortcomings in the treatment of CLIL in the training curricula may well help explain the finding that the new EHEA degrees are not properly training CLIL practitioners who work in the Madrid Autonomous Community (Custodio Espinar, 2020).

\section{Conclusions}

This study set out to investigate the role of English language improvement, teaching methodology, and CLIL in the design of the current ITE programmes in the Madrid Autonomous Community. Answering research question 1, the respective designs of the 14 EHEA 4-year long ITE programmes in the Madrid universities do reflect the rise of English as Europe's unquestionable lingua franca, as well as the higher demand of qualified EFL and CLIL primary teachers in the region brought about by its large-scale bilingual education programmes. This is evident from the increase in credit load devoted to English and foreign language pedagogy, which is higher than the national average, and which was found to be particularly noticeable in private universities.

Turning to the EFL formative itinerary, the first interesting finding of this study is that the minimum entry levels of English required by the different programmes tend to be low, with about two thirds of the programmes requiring CEFR levels B1, A2 or no requirement (research question 2). As to their curricular design (research question 3), the EFL itineraries have moved away from the theoretical, philological contents that used to be taught in the former specialist degrees, and now offer a heterogeneous combination of language improvement, language teaching methodology and, to a lesser extent, TEFL resources and CLIL. 
Finally, this analysis contributes to explaining, at least in part, the research findings that claim that, in general, student teachers in Madrid are not being properly trained in the principles and strategies of Content and Language Integrated Learning. Overall, the credit load devoted to CLIL appears to be insufficient and, when offered, inadequately placed at the end of the EFL itinerary and not as part of the core training of prospective teachers.

\section{Recommendations}

From the findings presented in this study, it is recommended that primary ITE programmes offer coursework on both foreign language teaching methodology and CLIL as part of their core curriculum; that is, outside of the EFL specialist itinerary. In what concerns language pedagogy, all trainees should develop an elementary understanding of the teaching pedagogy of one of the most prominent subjects in the school timetable. Among other benefits, this would enable more effective cooperation with the English language teachers.

Turning to CLIL, placing dedicated bilingual education modules in the core, nonspecialist training, would ensure that all future CLIL practitioners - who may or may not have followed the EFL formative itinerary - receive at least some training in the principles and strategies of the CLIL approach. Moreover, such training should be offered earlier on in the programme and, whenever possible, be integrated with other relevant modules (on Natural Science, Social Science, Arts \& Crafts and P.E.), as well as with the different teaching internships, many of which will take place in schools offering bilingual education.

Beyond the context of this study, these two recommendations may also be relevant in countries and regions that, like Spain, combine a low average level of English in teacher trainees with a commitment to a content-driven form of bilingual education that is largely taught by subject, not EFL specialist, teachers.

\section{Research limitations}

This study has several limitations that should be addressed by further research. Firstly, practicum and, to a lesser extent, the end of degree dissertation (TFG) should also be included in the analysis, in order to assess whether they are used by the different programmes to enhance their students' training as future EFL specialists or CLIL teachers. Secondly, a closer look into the broad area of language improvement is necessary. Indeed, it would be helpful to identify what the balance is between general English, English for Academic Purposes (EAP) and English for Specific Purposes (ESP), and whether the latter effectively targets the needs of prospective foreign language and CLIL teachers. In addition, EMI programmes in ITE should be carefully assessed in order to determine to what extent their students learn CLIL through exposure and practice, as well as enhancing their subject-specific and academic language skills. Finally, in what regard to data collection, more details could have been obtained regarding the treatment of CLIL in programmes lacking dedicated CLIL modules: for instance, number of hours of instruction and competences developed. 


\section{References}

Amengual-Pizarro, M. (2007). How to respond to the demands set by the communicative approach? New challenges L2 teachers face in the classroom. The European Journal of Teacher Education, 30(1), 63-73. http:/ / dx.doi.org/10.1080/02619760601120007

Amengual-Pizarro, M. (2013). Primary education degrees in Spain: do they fulfil the linguistic and pedagogic needs of future teachers? Vigo International Journal of Applied Linguistics, 10, 9-27. http://webs.uvigo.es/vialjournal/pdf/Vial-2013Article1.pdf

ANECA. (2005). Libro blanco. Título de Grado en Magisterio (vol. I and II.) Agencia Nacional de Evaluación de la Calidad y Acreditación. http:/ / www.aneca.es/Documentosy-publicaciones/Libros-Blancos

Ball, P., Clegg, J., \& Kelly, K. (2016). Putting CLIL into practice. Oxford University Press.

Cabezuelo, G. P., \& Fernández, F. R. (2014). A case study on teacher training needs in the Madrid bilingual project. Latin American Journal of Content $\mathcal{E}$ Language Integrated Learning, 7(2), 50-70. https:/ / doi.org/10.5294/4220

Comunidad de Madrid. (2006). Estudiar en Madrid: Universidades madrileñas. Curso 20062007. http:/ / www.madrid.org/universidades

Comunidad de Madrid. (2019). Datos y Cifras de la Educación 2018-2019. https://www.comunidad.madrid/sites/default/files/doc/educacion/sgea_dat osycifras_2019-20.pdf

Coyle, D., Hood, P., \& Marsh, D. (2010). CLIL: Content and language integrated learning. Cambridge University Press.

Custodio, E. M., \& García, R. J. M. (2020). Are Accredited Teachers Equally Trained for CLIL? The CLIL Teacher Paradox. Porta Linguarum, 33, 9-25. http:/ / hdl.handle.net/10481/62800

De La Maya Retamar, G., \& Luengo González, R. (2015). Teacher training programs and development of plurilingual competence. In D. Marsh, M. L. Pérez Cañado, \& J. Ráez Padilla (Eds.), CLIL in action: Voices from the classroom (pp. 114-129). Cambridge Scholars Publishing.

English First. (2020). EF English proficiency index. http://www.ef.com/epi

European Commission. (2012a). Eurobarometre 386: Europeans and their languages. http:/ / ec.europa.eu/public_opinion/archives/ebs/ebs_386_en.pdf.

European Commission. (2012b). European survey on language competences. http:/ / ec.europa.eu/languages/library/studies/executive-summaryeslc_en.pdf.

Eurydice. (2017). Key Data on Teaching Languages at School in Europe - 2017 Edition. Eurydice Report. Publications Office of the European Union. https:/ / eacea.ec.europa.eu/national-policies/eurydice/content/key-datateaching-languages-school-europe-\%E2\%80\%93-2017-edition_en

Fernández, R., \& Johnson, M. (2016). Opinions, perceptions and attitudes of a group of students taking a Bilingual Infant Teacher Training Degree: an empirical study. PULSO. Revista de Educación, 39, 59-78. https://revistas.cardenalcisneros.es/index.php/PULSO/article/view/214

Fernández-Viciana, A., \& Fernández-Costales, A. (2017). El pensamiento de los futuros maestros de inglés en Educación Primaria: creencias sobre su autoeficacia docente. Bellaterra Journal of Teaching E Learning Language E Literature, 10(1), 42 60. https://doi.org/10.5565/rev/jtl3.684

Flores, M. A. (2011). Curriculum of initial teacher education in Portugal: new contexts, old problems. Journal of Education for Teaching, 37(4), 461-470. https://doi.org/10.1080/02607476.2011.611015 
Freeman, D. (2016) Educating Second Language Teachers. Oxford University Press.

Frey, B. (2018). The SAGE encyclopedia of educational research, measurement, and evaluation (Vols. 1-4). SAGE Publications, Inc. https://dx.doi.org/10.4135/9781506326139.n547

García Jiménez, E., \& Lorente García, R. (2014). Grado en maestro de educación primaria: motivaciones y preferencias en la elección de mención. Aula de encuentro: Revista de investigación y comunicación de experiencias educativas, 16(1), 103-119. https://revistaselectronicas.ujaen.es/index.php/ADE/article/view/1297

Gutiérrez Gamboa, M., \& Custodio Espinar, M. (2021). CLIL teacher's initial education: a study of undergraduate and postgraduate student teachers. Encuentro Journal, 29, 104-119. http://www3.uah.es/encuentrojournal/index.php/encuentro/article/view/55

Halbach, A. (2020). English Language Teaching Goes CLIL: Fostering Literacy and Language Development in Secondary School in Spain. In P. Mickan, \& I. Wallace (Eds.), The Routledge Handbook of Language Education Curriculum Design (pp. 175189). Routledge.

Jeffrey, S., Rodríguez Melchor, D., \& Walsh, A. (2019). Linguistic requirements for students and staff on EMI undergraduate degrees at universities in the Community of Madrid. European Journal of Language Policy, 11, 95-107. https://doi.org/10.3828/ejlp.2019.6

Jiménez, E. G., \& García, R. L. (2014). Grado de maestro de educación primaria: motivaciones y preferencias en la elección de mención. Aula de encuentro: Revista de investigación y comunicación de experiencias educativas, 16(1), 103-119. https://revistaselectronicas.ujaen.es/index.php/ADE/article/view/1297

Jover, G., Fleta, T., \& González, R. (2016). La formación inicial de los maestros de educación primaria en el contexto de la enseñanza bilingüe en lengua extranjera. Bordón. Revista de Pedagogía, 68(2), 121-135. https://doi.org/10.13042/Bordon.2016.68208

Madrid Fernández, D. (2014). Integrating the European Portfolio in a competency-based teacher education approach. In J.D. Martínez Agudo (Ed.), English as a foreign language teacher education. Current perspectives and challenges (pp. 35-58). Rodopinde.

Madrid Manrique, M., \& Madrid Fernández, D. (2014). La formación inicial del profesorado para la educación bilingüe. Universidad de Granada.

Nunan, D. (2013). Research methods in language learning. Cambridge University Press.

Owen, G. T. (2014). Qualitative Methods in Higher Education Policy Analysis: Using Interviews and Document Analysis. The Qualitative Report, 19(26), 119. https:// doi.org/10.46743/2160-3715/2014.1211

Pavón, V.P., Lancaster, N., \& Callejas, C.B. (2020). Key issues in developing teachers' competences for CLIL in Andalusia: training, mobility and coordination. Language Learning Journal, 48(1), 81-98. https://doi.org/10.1080/09571736.2019.1642940

Perez-Cañado, M. L. (2016). Are teachers ready for CLIL? Evidence from a European study. European Journal of Teacher Education, 39(2), 202-221. https://doi.org/10.1080/02619768.2016.1138104

Pérez Cañado, M. L. (2017). CLIL teacher education: Where do we stand and where do we need to go? In M.E. Gómez Parra \& R. Johnstone (Eds.), Bilingual Education: Educational Trends and Key Concepts/ Educación Bilingüe: Tendencias Educativas y Conceptos Clave (pp. 129-144). Spanish Ministry of Education. https:// sede.educacion.gob.es/publiventa/educacion-bilinge-tendenciaseducativas-y-conceptos-claves--bilingual-educational-trends-and-keyconcepts/educacion-investigacion-educativa-lenguas/22107 
Pérez-Cañado, M. L. (2018). Innovations and Challenges in CLIL Teacher Training. Theory Into Practice, 57(3), 1-10. https://doi.org/10.1080/00405841.2018.1492238

Pérez Murillo, M. D., \& Steele, A. (2017). Initial Teacher Education for CLIL at Primary Education Level in Madrid: Key Issues and Challenges. In M.E. Gómez Parra M.E. \& R. Johnstone (Eds.), Bilingual Education: Educational Trends and Key Concepts/ Educación Bilingüe: Tendencias Educativas y Conceptos Clave (pp. 221-233). Spanish Ministry of Education. https://sede.educacion.gob.es/publiventa/educacionbilinge-tendencias-educativas-y-conceptos-claves--bilingual-educational-trendsand-key-concepts/educacion-investigacion-educativa-lenguas/22107

Ramos García, A. M. (2013) Higher Education Bilingual Programmes in Spain. Porta Linguarum, 19, 101-11. https://doi.org/10.30827/digibug.29632

Richards, J. C. (2017). Teaching English through English: Proficiency, pedagogy and $\begin{array}{llll}\text { performance. } & \text { RELC Journal, }\end{array}$ 30. https://doi.org/10.1177/0033688217690059

Scott, D., \& Beadle, S. (2014). Improving the effectiveness of language learning: CLIL and computer assisted language learning. European Commission. http://ir.uv.es/pOJh718

Sierra Macarrón, L., \& López-Hernández, A. (2015). CLIL en la formación inicial del profesorado de Educación Infantil y Primaria: la experiencia del CES Don Bosco. $\begin{array}{llll}\text { Educación } & y & \text { Futuro, 32, } & \text { 83-116. }\end{array}$ https://cesdonbosco.com/documentos/revistaeyf/EYF_32.pdf

Spain. Order ECI/3857/2007, 27th of December, that establishes the requirements for the recognition of official university degrees that serve as qualification for working as a Teacher of Primary Education. Boletin Oficial del Estado (Official State Bulletin), No. 312, 27 2007. https://www.boe.es/eli/es/o/2007/12/27/eci3857

Spain. Royal Decree 1594/2011, $9^{\text {th }}$ of November, that establishes the teaching specialisms in Primary and Infant Education. Boletín Oficial del Estado (Official State Bulletin), No. 270, $9^{\text {th }}$ of November 2011. https://www.boe.es/buscar/pdf/2011/BOE-A2011-17630-consolidado.pdf

Spain. Universities. Resolution, $26^{\text {th }}$ June 2000, of Autonomous University of Madrid, whereby the Degree structure of the Foreign Language (English) Primary Education Teaching Degree is published. Boletín Oficial del Estado (Official State Bulletin), No. 152, $26^{\text {th }}$ of June 2000. https://www.boe.es/boe/dias/2000/06/26/pdfs/A22573-22585.pdf

Young, J. W., Freeman, D., Hauck, M. C., Gomez, P. G., \& Papageorgiou, S. (2014). A Design Framework for the ELTeach Program Assessments. ETS Research Report Series, 2014, 1-29. https://doi.org/10.1002/ets2.12036 